\title{
Corporations and Governments: What Chance Does our Biosphere Have?
}

\author{
J. T. Trevors
}

Published online: 8 October 2009

(C) Springer Science + Business Media B.V. 2009

The recent 2008-2009 meltdown of the global economy, the subsequent printing of immense amounts of currency, corporate welfare bailouts and of course human greed and corruption demonstrate that we live in interesting times. The corporations and people that caused the global economic crisis are the very ones that dictated to the respective governments they must provide money to them. This is not even newsworthy as everyone knows that greedy people and corporations want as much money as possible for themselves when the capitalist economy is growing. But when the economy collapses, the greedy ones dictate to governments that they need corporate welfare to reboot the economy. Is this capitalism, or socialism or both depending on who wants the money. Most humans seem to be addicted to economic growth.

What chance does our common shared biosphere have when the greedy people dictate to governments how to run the economy. They must be special people. They must know things that other people do not know. They may even think they are clever, intellectual, smart, entitled, better educated and therefore should have what they want. All at the expense of other people and our common shared biosphere from where all profits ultimately arise. If they only knew how little they know and how unimportant their knowledge base is.

\section{J. T. Trevors $(\bowtie)$}

Department of Environmental Biology,

University of Guelph,

Guelph, ON, Canada NIG 2W1

e-mail: jtrevors@uoguelph.ca
What chance does humanity have in preserving our common shared biosphere when democratically elected governments are besieged by corporations and financial institutions that require the taxpayers' money to keep the credit flowing and the economy growing. Of course, a growing economy equates to depletion of global resources and more pollution until alternate technologies are in place. And if some humans do not deplete resources, the profits will not flow, and governments will not collect taxes, and people will be unemployed, and no one will buy the immense number of useless products manufactured at the expense of our biosphere. This of course would be a disaster of immense proportions because the wealthy must always be wealthy and the economy must grow. Actually, the economy does not need to grow. We simply need to decrease human population growth and conserve our blue planet. Humans can then focus on more honorable goals like universal human rights and the basic needs of life for everyone.

Corporations and greedy people do not dictate to governments that we all must preserve and improve our biosphere by decreasing human population growth and implementing conservation to reduce the impacts of global climate change. Global pollution has brought us to the edge or the beginning of total global warming from which there will be no economic bailout. Will there be a global environmental bailout? The rules of thermodynamics will not be broken as our planet warms from too many humans producing too much pollution. 